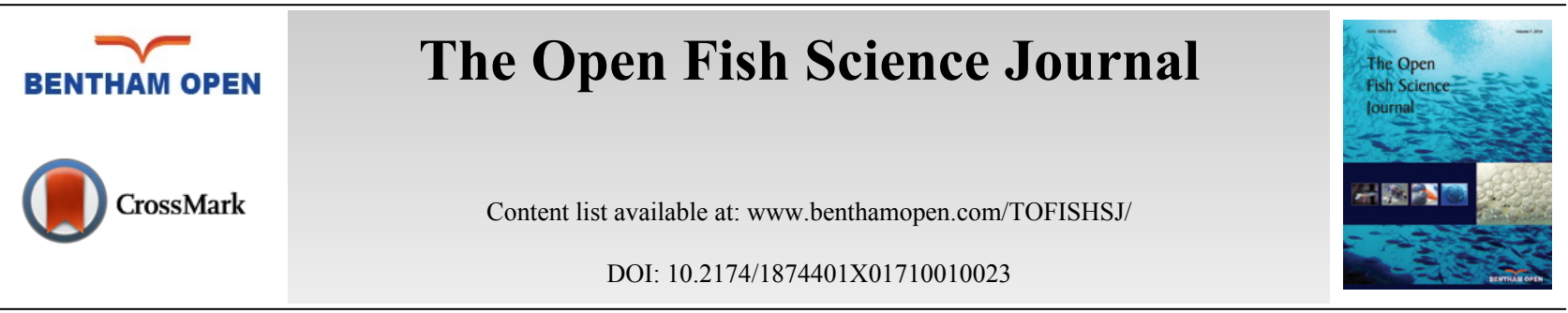

REVIEW ARTICLE

\title{
Landlocked Fall Chinook Salmon Maternal Liver and Egg Thiamine Levels in Relation to Reproductive Characteristics
}

\author{
Andrew Doyle ${ }^{1}$, Michael E. Barnes, ${ }^{2, *}$, Jeremy L. Kientz ${ }^{2}$ and Micheal H. Zehfus ${ }^{3}$ \\ ${ }^{I}$ Department Benedictine College Atchison, Kansas, United States \\ ${ }^{2}$ McNenny State Fish Hatchery South Dakota Department of Game, Fish and Parks Spearfish, South Dakota, United \\ States \\ ${ }^{3}$ Department of Chemistry Black Hills State University, University Spearfish, South Dakota, United States
}

Received: November 11, 2016

Revised: January 04, 2017

Accepted: January 23, 2017

\begin{abstract}
:
Object:

Landlocked fall Chinook Salmon Oncorhynchus tshawytscha in Lake Oahe, South Dakota, typically experience poor reproductive success.
\end{abstract}

\section{Introduction:}

Salmon diets consist of rainbow smelt Osmerus mordax and other potentially thiaminase-containing fish that could impact reproduction.

\section{Methods:}

The thiamine levels of spawning female Salmon, eggs, and reproductive characteristics, were measured in 2000, 2001, 2002, 2003, and 2005 .

\section{Results:}

Thiamine concentrations varied significantly from year-to-year, with the highest mean values recorded in $2001 \mathrm{at} 8.70 \mathrm{nmol} / \mathrm{g}$ in maternal livers and $28.80 \mathrm{nmol} / \mathrm{g}$ in eggs. Most of the thiamine in the eggs was present as free thiamine, while most of the thiamine in maternal livers was present as thiamine pyrophosphate. The lowest recorded egg total thiamine level was $2.75 \mathrm{nmol} / \mathrm{g}$ in 2000 . Egg survival to hatch ranged from $20.7 \%$ in 2005 to $35.4 \%$ in 2002, and was not correlated to egg thiamine levels. Twenty-two spawns experienced total mortality prior to hatch, and had significantly lower egg free thiamine and total thiamine concentrations than eggs from the 77 successful spawns. The eggs from spawns with total mortality were also significantly smaller than those eggs from spawns that did survive, and were produced by females that weighed significantly less. Several small, but significant, correlations were observed between egg size and egg thiamine levels, and female size and liver thiamine.

There was also a significant negative correlation between the number of eggs per spawning female and egg thiamine pyrophosphate, liver thiamine monophosphate, and liver total thiamine levels.

\section{Conclusion:}

In general, Lake Oahe Chinook Salmon eggs show little indication of thiamine deficiency in the years sampled, indicating other factors are likely responsible for poor egg survival.

Keywords: Thiamine, Chinook Salmon, Reproduction, Rainbow Smelt, Thiaminase, Lake Oahe

\footnotetext{
* Address correspondence to this author at the McNenny State Fish Hatchery South Dakota Department of Game, Fish and Parks Spearfish, South Dakota, United States, Tel: 605-642-6920, Fax: 605-642-6921; E-mail: mike.barnes@state.sd.us
} 


\section{INTRODUCTION}

Eggs collected from free-ranging fall Chinook Salmon Oncorhynchus tshawytscha in Lake Oahe, South Dakota (USA) typically experience poor survival during hatchery rearing [1], with survival less than one-half that observed for Chinook Salmon in their native range [2,3]. The reason for this elevated egg mortality is currently unknown, but may be due to several factors, including elevated water temperatures during oogenesis and spawning $[4,5]$, parental nutrition $[1,6,7]$, and possible inbreeding $[1,8,9]$. One aspect of parental nutrition that may be influencing reproductive success are thiamine (vitamin B1) levels in the eggs.

In fish, thiamine is found in three different forms or vitamers: thiamin pyrophosphate (TPP), thiamine monophosphate (TMP), and free thiamine. Thiamine pyrophosphate and thiamine monophosphate are the two biologically active forms [10]. TPP and TMP are cofactors required for fatty acid and carbohydrate metabolism, specifically the pyruvate decarboxylase complex and enzymes involved in the Krebs cycle [10]. Without these enzymes, aerobic respiration will cease. In addition, thiamine deficiencies are also linked with neurological degenerative disorders such as Weirnkie's syndrome [10]. Without thiamine, organisms become lethargic and eventually die because of the decrease in metabolism and neuron degeneration.

Rainbow smelt Osmerus mordax are the primary prey item for Lake Oahe Chinook Salmon when they are abundant [11]. Rainbow smelt contain thiaminases, a group of enzymes that break down thiamine [12 - 14]. Mortality of Salmonid embryos from thiamine deficiencies resulting from the parental consumption of thiaminase-containing prey has been observed in the Baltic Sea, the Finger Lakes of New York, and the Great Lakes [15 - 19]. Depending on geography, this mortality was initially called M74, Cayuga syndrome, swim-up syndrome, and Early Mortality Syndrome [20]. However, all these syndromes have now been grouped together as the thiamine deficiency complex [21]. During certain years of hatchery rearing, Lake Oahe Salmon exhibits some of the clinical signs, and mortality patterns, associated with thiamine deficiency complex.

Only one preliminary study has described thiamine levels in Lake Oahe Chinook Salmon and eggs [22]. However, this study lasted for only one year, during which rainbow smelt population abundance was low. Smelt and other prey fish populations fluctuate substantially from year-to-year in Lake Oahe, and it is possible that spawning female and egg thiamine levels fluctuate as well. The objective of this study is to document levels of maternal liver and egg thiamine concentrations in conjunction with the reproductive success of Lake Oahe Chinook Salmon over several years.

\section{MATERIALS AND METHODS}

\section{Study Area}

Lake Oahe is a 150,000 ha mainstem Missouri River reservoir located in North and South Dakota, USA. The South Dakota portion contains approximately 47,755 ha of coldwater habitat (water temperatures $\leq 15^{\circ} \mathrm{C}$ ) at full pool [23]. Suitable permanent habitat for Chinook Salmon is typically located directly upstream from Lake Oahe dam, north of Pierre, South Dakota, to Whitlock's Bay, west of Gettysburg, South Dakota, USA. Female Salmon and eggs used for this study were collected during spawning of feral Chinook Salmon at Whitlocks Spawning Station on Lake Oahe near Gettysburg, South Dakota. Egg incubation occurred at McNenny State Fish Hatchery, rural Spearfish, South Dakota.

\section{Spawning and Egg Incubation}

Eggs were pneumatically removed from ripe, free-ranging females that had ascended the fish ladder at Whitlock's Spawning Station. Prior to gamete collection, male and female Salmon were anesthetized in carbon-dioxide saturated water. Milt was collected from males by hand-stripping, pooled in a container, and kept on ice until it was used to fertilize the eggs. Eggs were removed from ripe females by injecting compressed oxygen at low pressure into their body cavities and the eggs were expressed into a plastic pan. Lake water $\left(11-13^{\circ} \mathrm{C}\right.$, total hardness as $\mathrm{CaCO}_{3}=160 \mathrm{mg} / \mathrm{L}, \mathrm{pH}$ $=8.2$, total dissolved solids $=440 \mathrm{mg} / \mathrm{L}$ ) was added to the pan to activate the milt. After approximately one minute, eggs were washed in lake water to remove excess milt, and then placed in lake water for one-hour to allow for membrane separation (water hardening). After water hardening, the eggs were placed in plastic bags with fresh lake water, and transported approximately 4 hours to McNenny Hatchery. The spawn from each female was maintained discretely during the spawning process, transportation to the hatchery, and during incubation. Based on historical norms and the size of fish at spawning, it was assumed that only age-3 Salmon were used in the study [24].

Upon arrival at McNenny Hatchery, the eggs were disinfected in a $100 \mathrm{mg} / \mathrm{L}$ buffered free-iodine solution for 10 
min, inventoried by the water displacement method [25], and placed in individual Heath (Flex-a-lite Consolidated, Tacoma, Washington) incubator trays. Well water $\left(11^{\circ} \mathrm{C}\right.$, total hardness as $\mathrm{CaCO}_{3}-360 \mathrm{mg} / \mathrm{L}$, alkalinity as $\mathrm{CaCO}{ }_{3}-$ $210 \mathrm{mg} / \mathrm{L}$, pH - 7.6, total dissolved solids $-390 \mathrm{mg} / \mathrm{L}$ ) at a flow of $12 \mathrm{~L} / \mathrm{min}$ was used for egg incubation. Formalin treatments using Parasite-S (37\% formaldehyde, 6 to 14\% methanol, Western Chemical Inc., Ferndale, Washington) at $1,667 \mathrm{mg} / \mathrm{L}$ for $15 \mathrm{~min}$ were administered daily until retinal pigments were clearly visible (egg eye-up) at incubation d 30, after which dead eggs were removed and percent survival to eye-up calculated. After egg eye-up, additional dead eggs and dead fry were removed by hand until the fry had nearly completed yolk sac absorption and were moved from the incubator. Survival to the eyed stage of development, hatch, and fry swim-up was calculated using the following formulas:

Survival to the eye (\%)

$=100 \mathrm{X}[1-($ mortality at the eyed stage / initial number of eggs $)]$.

Survival to hatch $(\%)$

$=100 \mathrm{X}[1-($ mortality up to hatch / initial number of eggs $)]$.

Survival to swim-up (\%)

$=100 \mathrm{X}[1-($ total mortality during incubation / initial number of eggs $)]$.

\section{Thiamine Analysis}

Immediately after removal from the female, approximately $20 \mathrm{~g}$ of eggs were placed into plastic bags, quickly frozen using dry ice, and subsequently stored in a $-70^{\circ} \mathrm{C}$ freezer until analyzed for thiamine content. Immediately after spawning, the liver was removed from each spawning female, quickly frozen using dry ice, and stored at $-70^{\circ} \mathrm{C}$ until thiamine analysis occurred. Thiamine pyrophosphate, thiamine monophosphate, and free thiamine were analyzed using a high pressure liquid chromatography method [26]. Total thiamine was calculated by adding the vitamers.

\section{Data Analysis}

Data was analyzed using the SPSS (9.0) statistical analysis program (SPSS, Chicago, Illinois, USA). Regression and correlation analysis were used to ascertain any possible relationships among the variables. Yearly data was analyzed using ANOVA and Tukey means comparison procedure. The significance level for all tests was predetermined at $P<$ 0.05 .

\section{RESULTS}

Egg and maternal liver thiamine concentrations varied significantly from year-to-year (Table 1). Free and total thiamine levels in the eggs were the highest in 2001, followed by 2002, with the lowest levels recorded in 2000,2003 and 2005. Maternal liver TMP and total thiamine were also significantly greater in 2001 compared to the other years. Egg total thiamine levels ranged from 2.75 to $45.25 \mathrm{nmol} / \mathrm{g}$, and maternal liver total thiamine levels ranged from 1.05 to $16.65 \mathrm{nmol} / \mathrm{g}$. Most of the thiamine in the eggs was present as free thiamine, whereas TPP was the predominant form of thiamine found in maternal livers.

Table 1. Mean (SE) spawning female sizes, reproductive data, and thiamine data from landlocked fall Chinook Salmon from Lake Oahe, South Dakota. Means with different letters across a row are significantly different $(P<0.05)$.

\begin{tabular}{|c|c|c|c|c|c|}
\hline & 2000 & 2001 & 2002 & 2003 & 2005 \\
\hline $\mathbf{N}$ & 21 & 21 & 17 & 20 & 20 \\
\hline Length (mm) & $678 \pm 13 y$ & $690 \pm 44 y$ & $776 \pm 55 \mathrm{z}$ & $810 \pm 6 z$ & $722 \pm 15 y$ \\
\hline Weight $(\mathrm{g})$ & $2,019 \pm 143 x$ & $2,999 \pm 152 \mathrm{y}$ & NA & $4,442 \pm 141 \mathrm{z}$ & $3,489 \pm 334 y$ \\
\hline Egg Size (number/ml) & $6.9 \pm 0.4 \mathrm{x}$ & $4.6 \pm 0.2 \mathrm{z}$ & $5.1 \pm 0.3 \mathrm{zy}$ & $4.4 \pm 0.1 \mathrm{z}$ & $5.9 \pm 0.1 \mathrm{y}$ \\
\hline Number of Eggs & $2,011 \pm 160 \mathrm{x}$ & $2,374 \pm 161 x$ & $4,067 \pm 259 \mathrm{zy}$ & $4,555 \pm 151 \mathrm{z}$ & $3,311 \pm 261 \mathrm{y}$ \\
\hline Survival to Eyeup (\%) & $36.4 \pm 6.5 \mathrm{z}$ & $31.5 \pm 8.9 \mathrm{z}$ & $38.1 \pm 6.8 \mathrm{z}$ & $29.1 \pm 4.7 \mathrm{z}$ & $25.0 \pm 5.3 \mathrm{z}$ \\
\hline Survival to Hatch (\%) & $27.9 \pm 6.7 \mathrm{z}$ & $27.4 \pm 3.7 \mathrm{z}$ & $35.4 \pm 5.6 \mathrm{z}$ & $25.8 \pm 5.0 \mathrm{z}$ & $20.7 \pm 4.7 \mathrm{z}$ \\
\hline Survival to Swim-up (\%) & $27.7 \pm 6.7 \mathrm{z}$ & $27.2 \pm 3.7 \mathrm{z}$ & $35.2 \pm 5.5 \mathrm{z}$ & $25.3 \pm 5.0 \mathrm{z}$ & $17.6 \pm 3.8 \mathrm{z}$ \\
\hline Egg TPP $(\mathrm{nmol} / \mathrm{g})$ & $0.65 \pm 0.05 \mathrm{z}$ & $0.40 \pm 0.05 \mathrm{zy}$ & $0.40 \pm 0.05 \mathrm{zy}$ & $0.30 \pm 0.05 \mathrm{y}$ & $0.65 \pm 0.05 \mathrm{z}$ \\
\hline $\operatorname{Egg~TMP}^{2}(\mathrm{nmol} / \mathrm{g})$ & $0.55 \pm 0.05 \mathrm{z}$ & $0.50 \pm 0.05 \mathrm{z}$ & $0.65 \pm 0.05 \mathrm{z}$ & $0.40 \pm 0.05 \mathrm{z}$ & $0.45 \pm 0.05 \mathrm{z}$ \\
\hline
\end{tabular}


(Table 1) contd....

\begin{tabular}{|c|c|c|c|c|c|}
\hline & 2000 & 2001 & 2002 & 2003 & 2005 \\
\hline $\mathbf{N}$ & 21 & 21 & 17 & 20 & 20 \\
\hline Egg Free Thiamine $(\mathrm{nmol} / \mathrm{g})$ & $10.10 \pm 1.25 \mathrm{x}$ & $27.95 \pm 2.15 \mathrm{z}$ & $21.05 \pm 0.90 \mathrm{y}$ & $15.55 \pm 1.60 \mathrm{yx}$ & $12.55 \pm 1.00 \mathrm{x}$ \\
\hline Egg Total Thiamine (nmol/g) & $11.25 \pm 1.25 \mathrm{x}$ & $28.80 \pm 2.20 \mathrm{z}$ & $22.10 \pm 3.60 \mathrm{y}$ & $16.25 \pm 1.65 \mathrm{yx}$ & $13.60 \pm 1.05 x$ \\
\hline Liver TPP ${ }^{1}(\mathrm{nmol} / \mathrm{g})$ & $3.45 \pm 0.40 \mathrm{zy}$ & $4.30 \pm 0.45 \mathrm{zy}$ & $2.79 \pm 0.25 \mathrm{yx}$ & $4.00 \pm 0.20 \mathrm{zy}$ & $5.00 \pm 3.90 \mathrm{z}$ \\
\hline Liver TMP ${ }^{2}(\mathrm{nmol} / \mathrm{g})$ & $1.95 \pm 0.30 \mathrm{y}$ & $3.10 \pm 0.40 \mathrm{z}$ & $1.15 \pm 0.15 \mathrm{yx}$ & $1.25 \pm 0.05 \mathrm{yx}$ & $0.82 \pm 0.10 \mathrm{x}$ \\
\hline Liver Free Thiamine $(\mathrm{nmol} / \mathrm{g})$ & $0.40 \pm 0.05 \mathrm{yx}$ & $1.30 \pm 0.20 \mathrm{z}$ & $0.80 \pm 0.05 \mathrm{zy}$ & $0.35 \pm 0.05 \mathrm{yx}$ & $0.25 \pm 0.05 \mathrm{x}$ \\
\hline Liver Total Thiamine $(\mathrm{nmol} / \mathrm{g})$ & $5.80 \pm 0.60 \mathrm{y}$ & $8.70 \pm 0.90 \mathrm{z}$ & $4.75 \pm 0.35 \mathrm{y}$ & $4.45 \pm 0.55 \mathrm{y}$ & $5.95 \pm 0.75 \mathrm{y}$ \\
\hline
\end{tabular}

${ }^{1} \mathrm{TPP}=$ thiamine pyrophosphate ${ }^{2} \mathrm{TMP}=$ thiamine monophosphate.

Overall mean survival to the eyed-egg stage was only $31.9 \%$, with mean survival to fry swim-up at $26.4 \%$. No significant differences in egg or fry survival were observed among any of the years. Survival to the eyed-egg stage and fry swim-up of the spawn containing eggs with $2.75 \mathrm{nmol} / \mathrm{g}$ total thiamine was $68 \%$ and $62 \%$, respectively.

In comparison to eggs from spawns that failed to hatch, eggs from successful spawns with at least some survival to hatch had a significantly greater concentration of free thiamine $(13.75$ to $18.40 \mathrm{nmol} / \mathrm{g})$ and total thiamine (14.85 to $19.35 \mathrm{nmol} / \mathrm{g}$ ) (Table 2). Egg TPP and Egg TMP were not significantly different from the two groups. None of the liver thiamine vitamers were significantly different as well. The eggs that did not hatch were significantly smaller (smaller eggs have a higher number of eggs/ $\mathrm{ml}$ of water displaced) and came from larger females.

Table 2. Mean (SE) spawning female sizes, reproductive data, and thiamine data from spawns of landlocked fall Chinook Salmon from Lake Oahe, South Dakota that either had some eggs survive to hatch or experienced complete mortality. Means with different letters across a row are significantly different $(P<0.05)$.

\begin{tabular}{|c|c|c|}
\hline & 0\% Hatch & $>0 \%$ Hatch \\
\hline Number & 22 & 77 \\
\hline Length $(\mathrm{mm})$ & $713 \pm 15 \mathrm{z}$ & $738 \pm 8 \mathrm{z}$ \\
\hline Weight $(\mathrm{g})$ & $2,726 \pm 240 y$ & $3,427 \pm 172 \mathrm{z}$ \\
\hline Egg Size $(\# / \mathrm{ml})$ & $6.3 \pm 0.4 \mathrm{z}$ & $5.1 \pm 0.1 \mathrm{y}$ \\
\hline Number of Eggs & $2,886 \pm 317 \mathrm{z}$ & $3,217 \pm 132 \mathrm{z}$ \\
\hline Survival to Eyeup (\%) & $6.6 \pm 2.0 \mathrm{y}$ & $39.1 \pm 2.4 \mathrm{z}$ \\
\hline Survival to Hatch (\%) & $0.0 \pm 0.0 \mathrm{y}$ & $35.0 \pm 2.3 \mathrm{z}$ \\
\hline Survival to Swim-up (\%) & $0.0 \pm 0.0 \mathrm{y}$ & $33.9 \pm 2.3 \mathrm{z}$ \\
\hline $\operatorname{Egg~TPP}^{1}(\mathrm{nmol} / \mathrm{g})$ & $0.45 \pm 0.05 \mathrm{z}$ & $0.50 \pm 0.10 \mathrm{z}$ \\
\hline $\operatorname{Egg~TMP}^{2}(\mathrm{nmol} / \mathrm{g})$ & $0.65 \pm 0.15 \mathrm{z}$ & $0.45 \pm 0.05 \mathrm{z}$ \\
\hline Egg Free Thiamine $(\mathrm{nmol} / \mathrm{g})$ & $13.75 \pm 1.25 \mathrm{y}$ & $18.40 \pm 1.10 \mathrm{z}$ \\
\hline Egg Total Thiamine $(\mathrm{nmol} / \mathrm{g})$ & $14.85 \pm 1.30 \mathrm{y}$ & $19.35 \pm 1.10 \mathrm{z}$ \\
\hline Liver TPP ${ }^{1}(\mathrm{nmol} / \mathrm{g})$ & $4.15 \pm 0.40 \mathrm{z}$ & $4.00 \pm 0.25 \mathrm{z}$ \\
\hline Liver TMP $^{2}(\mathrm{nmol} / \mathrm{g})$ & $1.85 \pm 1.15 \mathrm{z}$ & $1.70 \pm 0.20 \mathrm{z}$ \\
\hline Liver Free Thiamine (nmol/g) & $0.50 \pm 0.10 \mathrm{z}$ & $0.65 \pm 0.05 \mathrm{z}$ \\
\hline Liver Total Thiamine $(\mathrm{nmol} / \mathrm{g})$ & $5.95 \pm 0.60 \mathrm{z}$ & $6.15 \pm 0.45 \mathrm{z}$ \\
\hline
\end{tabular}

${ }^{1} \mathrm{TPP}=$ thiamine pyrophosphate

${ }^{2} \mathrm{TMP}=$ thiamine monophosphate.

There were no significant correlations observed among survival to the eyed-egg stage, hatch, or fry swim-up and any of the thiamine forms or total thiamine. Egg TPP, TMP, free thiamine, and total thiamine levels were significantly, but weakly, correlated with egg size (Table 3). Small, but significant, correlations were also observed between the number of eggs and liver thiamine levels. Liver free thiamine was significantly correlated with egg free and total thiamine concentrations. There were significant, but weak, correlations between liver total thiamine and spawning female length and weight. Two significant regressions were calculated based on the natural log transformation of egg total thiamine data in relation to the survival from the eyed-egg stage of development to hatch (Fig. 1) and survival from the eyed-egg stage to fry swim-up (Fig. 2).

Female lengths, weights, egg size, and the number of eggs per spawn were significantly different among the years. Fish were the largest in 2002 and 2003. There were significantly fewer eggs per spawn in 2000 and 2001 compared to the other three years and the smallest eggs were observed in 2000, followed by 2005, and then 2001-2003. 


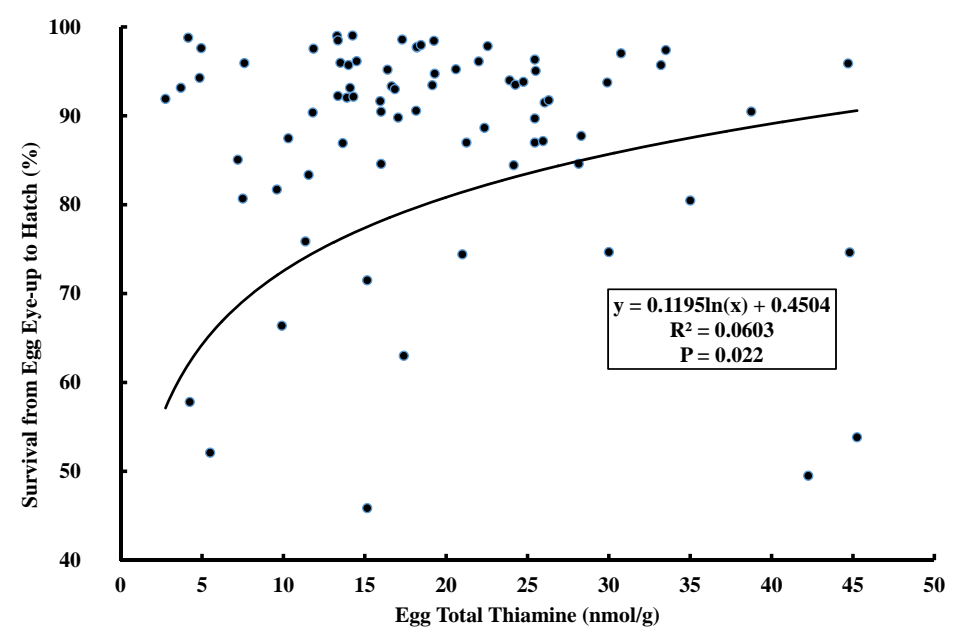

Fig. (1). Survival from the eyed egg stage to hatch of landlocked Chinook Salmon from Lake Oahe, South Dakota in relation to total egg thiamine from 2000 to $2005(n=77)$.

\section{DISCUSSION}

At $2.75 \mathrm{nmol} / \mathrm{g}$, the lowest concentration of egg total thiamine in the eggs from one spawning female was above the $1.7 \mathrm{noml} / \mathrm{g}$ upper boundary for thiamine deficiency complex identified by [27 - 30]. However, this value $(2.75 \mathrm{nmol} / \mathrm{g})$ was slightly less than the $2.99 \mathrm{nmol} / \mathrm{g}$ total thiamine value reported to produce $20 \%$ mortality in Lake Ontario Chinook Salmon eggs [31], but the overall high survival of the fry, and the lack of substantial post-hatch mortality, from this spawn appears to indicate that mortality due to thiamine deficiency did not occur. Of the 99 spawns sampled in this study, only three showed survival of less than $90 \%$ between hatch and swim-up, which is the most lethal period for thiamine deficiency complex [28]. Of these, the lowest concentration of total egg thiamine was $9.25 \mathrm{nmol} / \mathrm{g}$, much greater than the concentration considered the upper end of the thiamine deficiency complex [28, 31], making it unlikely that a lack of thiamine was the cause of fry mortality. The adequacy of thiamine levels in Lake Oahe Salmon observed in this study is further supported by the similar hatch to swim-up survival rates of Lake Oahe Salmon eggs to eggs treated with supplemental thiamine from populations with a history of thiamine deficiency complex $[15,16,20]$.

Table 3. Significant correlations between the variables $(P<0.05)$.

\begin{tabular}{|c|c|c|c|}
\hline Variable 1 & Variable 2 & P & r \\
\hline Egg TPP1 & Egg Size & 0.000 & 0.346 \\
\hline Egg TPP1 & Number of Eggs & 0.033 & -0.215 \\
\hline Egg TMP2 & Egg Size & 0.039 & 0.208 \\
\hline Egg Free Thiamine & Egg Size & 0.003 & -0.293 \\
\hline Egg Free Thiamine & Egg Total Thiamine & 0.000 & 0.998 \\
\hline Egg Free Thiamine & Liver TMP2 & 0.005 & 0.297 \\
\hline Egg Free Thiamine & Liver Free Thiamine & 0.000 & 0.528 \\
\hline Egg Total Thiamine & Liver TMP2 & 0.005 & 0.294 \\
\hline Egg Total Thiamine & Liver Free Thiamine & 0.000 & 0.528 \\
\hline Egg Total Thiamine & Egg Size & 0.008 & -0.267 \\
\hline Liver TPP1 & Liver TMP2 & 0.000 & 0.366 \\
\hline Liver TPP1 & Liver Total Thiamine & 0.000 & 0.816 \\
\hline Liver TMP2 & Length & 0.001 & -0.352 \\
\hline Liver TMP2 & Number of Eggs & 0.000 & -0.416 \\
\hline Liver TMP2 & Liver Free Thiamine & 0.000 & 0.747 \\
\hline Liver TMP2 & Liver Total Thiamine & 0.000 & 0.815 \\
\hline Liver Free Thiamine & Number of Eggs & 0.037 & -0.223 \\
\hline Liver Free Thiamine & Liver Total Thiamine & 0.000 & 0.649 \\
\hline Liver Total Thiamine & Length & -0.326 \\
\hline Liver Total Thiamine & Weight & -0.298 \\
\hline
\end{tabular}


(Table 3) contd.....

\begin{tabular}{|c|c|c|c|}
\hline Variable 1 & Variable 2 & $\mathbf{P}$ & $\mathbf{r}$ \\
\hline Liver Total Thiamine & Number of Eggs & 0.000 & -0.364 \\
\hline Length & Egg Size & 0.000 & -0.525 \\
\hline Length & Number of Eggs & 0.000 & 0.684 \\
\hline Weight & Egg Size & 0.000 & 0.729 \\
\hline Egg Size & Number of Eggs & 0.000 & -0.372 \\
\hline Egg Size & Survival to Hatch & 0.050 & -0.197 \\
\hline Egg Size & Survival to Swim-up & 0.042 & -0.205 \\
\hline Survival to Hatch & Number of Eggs & 0.050 & 0.198 \\
\hline Survival to Hatch & Survival to Eye-up & 0.000 & 0.963 \\
\hline Survival to Hatch & Survival to Swim-up & 0.000 & 0.994 \\
\hline Survival to Swim-up & Survival to Eye-up & 0.000 & 0.954 \\
\hline
\end{tabular}

${ }^{1} \mathrm{TPP}=$ thiamine pyrophosphate

${ }^{2} \mathrm{TMP}=$ thiamine monophosphate.

The lowest egg total thiamine concentration observed from any spawn during the five years of this study was only slightly lower than the $3.5 \mathrm{nmol} / \mathrm{g}$ lowest measurement reported previously for eggs from Lake Oahe Chinook Salmon during a year when smelt were less numerous [22]. Eggs from two of the years had similar total thiamine values to the $9.9 \mathrm{nmol} / \mathrm{g}$ mean value in 1999 reported [22]. However, mean values from the other three years were dramatically larger, approaching nearly $29 \mathrm{nmol} / \mathrm{g}$ in 2003. The highest recorded egg total thiamine level was also nearly three times that reported by [22].

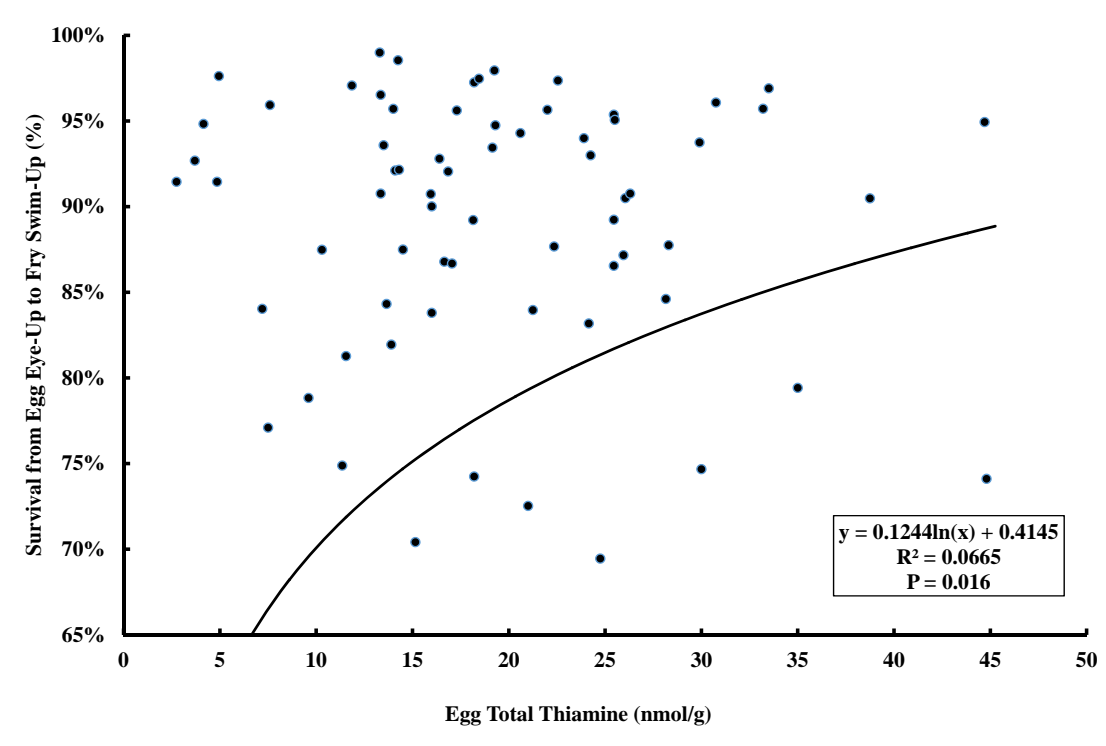

Fig. (2). Survival from egg eye-up to fry swim-up of landlocked Chinook Salmon from Lake Oahe, South Dakota in relation to total egg thiamine from 2000 to $2005(n=77)$.

Overall, thiamine levels in Chinook Salmon eggs from Lake Oahe are far greater than levels found in the Great Lakes or the Baltic Sea, where thiamine deficiency complex is frequently observed. The minimum total egg thiamine level observed in this study is typical of Chinook Salmon eggs that did not exhibit thiamine deficiency complex from Lakes Michigan and Huron [30]. In Lake Michigan, Lake Huron, and Lake Ontario, mean egg total thiamine levels for Salmonids have been reported as 2.0,3.1, and $1.3 \mathrm{nmol} / \mathrm{g}$, respectively [32]. In the Baltic Sea, egg mean total thiamine levels of $2.7 \mathrm{nmol} / \mathrm{g}$ have been reported [33]. The mean values from Lake Oahe Chinook Salmon eggs in the current study are as high as ten times greater as these other locations. However, the lowest levels observed in this study are similar to those reported for suspected thiamine-deficient eggs from migratory Chinook Salmon in New York [34].

Thiamine deficiency complex may not be a problem for the Salmon in Lake Oahe because the concentration of thiaminase in rainbow smelt may not be sufficient for induction of the complex [16]. The amount of thiaminase in rainbow smelt is up to six times less than the amount in alewife Alosa pseudoharengus [16,35]. Thiaminase activity is 
also four times lower in smelt than in Baltic herring Clupea harengus [36]. The thiaminase from rainbow smelt may also be diluted by other prey items in the diet of Lake Oahe Chinook Salmon [22], making it likely that there may not be enough thiaminase in the Salmon diet to induce thiamine deficiency complex [37].

The reason for the significantly lower levels of thiamine from spawns where none of the eggs survived to hatch versus successful spawns is unknown. Because of the high prevalence of overripe and nonviable spawns in Lake Oahe Salmon [38], it is possible that thiamine was degraded due to cell death and not because of the action of thiaminase. Twelve of the spawns in the current study had no survival to the eyed-egg stage of development, and were likely nonviable prior to spawning. It is also possible that the thiamine requirements for Oahe Salmon are greater than those in other locations, or there is an interaction between thiamine and other nutritional components, such as fatty acids or bioenergetics [37, 39 - 42].

Lake Oahe Chinook Salmon are considerably smaller than Chinook Salmon in their native range, likely due to nutritional deficiencies resulting from a total freshwater lifecycle in a reservoir with limited coldwater forage [1]. Lake Oahe Salmon also produce smaller eggs than ocean stocks [1], and the eggs from spawns with no survival in this study were significantly smaller than eggs from spawns with at least some survival. These very small eggs also contained less thiamine, opening the possibility of an interaction between thiamine and other dietary components consumed by the brood female [37, 39 - 42]. In Lake Oahe Salmon, egg thiamine levels increased with egg size (note that with egg sizes measured as eggs/mL, smaller values represent larger eggs), and egg size increased with maternal length and weight. These larger fish producing larger eggs had a greater ability to acquire more or higher quality food resources [43], which may explain why the eggs from spawns with no survival were smaller and contained less thiamine than eggs that survived.

All of the mean maternal liver total thiamine values were approximately one-third to one-half that reported for Lake Oahe Salmon in 1999 [22]. The Lake Oahe rainbow smelt population also increased after 1999, which may explain this decrease in maternal thiamine. Perhaps of more interest, with the exception of 2001, mean maternal liver total thiamine levels were less than the level of total liver thiamine $(6.3 \mathrm{nmol} / \mathrm{g})$ in healthy Atlantic Salmon [18], and very similar to Great Lakes Salmonids producing progeny with Thiamine Deficiency Complex [44]. These relatively low levels may not be lethal, but lower thiamine levels can impact adult fish neurological function [19, 45], metabolic rates [15, 28], and muscle weakness [34], thereby potentially decreasing foraging efficiency and subsequently contributing to smaller body sizes $[22,28]$.

Similar to that reported by other authors $[14,17,30,46]$, free thiamine was the most prevalent form of thiamine in Lake Oahe Chinook Salmon eggs. Free thiamine likely acts as a storage vitamer and is converted to TPP or TMP later during development [46]. In contrast, TPP was the predominant vitamer in adult tissue. This has also been observed with other adult Salmonids [20,47], and is not surprising given that TPP is a biologically-active form of thiamine required for cellular metabolism [10].

The relatively weak, but significant, positive correlation between egg size and egg survival observed in this study has been reported for other Salmonids [6, 48]. In contrast, inverse relationships between Chinook Salmon egg size and subsequent survival have been documented, with larger eggs experiencing higher mortality [49]. This was also observed during one year with Lake Oahe Chinook Salmon eggs [1]. However, studies with Chinook Salmon and other Salmonids have found no correlation between the egg size and survival [1, 50, 51].

Even though the Chinook Salmon eggs in this study did not appear to be thiamine deficient, survival was still very poor. Survival to the eyed-egg stage of development has been reported from $83 \%$ to $98 \%$ from Chinook Salmon in their native range [3, 28, 52, 53]. Egg survival in 2003 and 2005 was also dramatically lower than that previously reported for Lake Oahe Chinook Salmon [1]. Elevated water temperatures during gamete formation and maturation, energyrelated maternal dietary issues, and genetic inbreeding may all contribute to the observed poor reproductive success [1, $7,8,54]$.

\section{CONCLUSION}

Egg and maternal liver thiamine concentrations in landlocked fall Chinook Salmon from Lake Oahe vary dramatically from year-to-year, likely due to the considerable changes in Salmon prey species abundance and availability that frequently occur in Lake Oahe $[1,55]$. The effects on adult fish physiology of relatively low levels of thiamine in maternal livers are unknown, and further research is needed. Lake Oahe Chinook Salmon eggs show no indication of thiamine deficiency, but survival is still relatively poor. Further research is also needed to ascertain the 
reason for lower thiamine levels in eggs from spawns that experienced total mortality in comparison to successful spawns.

\section{CONSENT FOR PUBLICATION}

Not applicable.

\section{CONFLICT OF INTEREST}

The author (editor) declares no conflict of interest, financial or otherwise.

\section{ACKNOWLEDGEMENTS}

Funding for this study was partially provided by Federal Aid in Sport Fish Restoration, project F-21-R, study 1587. We thank Jonathan A. Schumacher, Kelly S. Stock, Faraz Farrokhi, Rebecca L. Nutter, Rick Cordes, Will Sayler, Kody Steinbrecher, Fritz Fonck, Dave Stout, Bernie Heath, Brian Smith, John Lott, and Robert P. Hanten for their assistance with egg and tissue collection, thiamine analysis, and egg incubation.

\section{REFERENCES}

[1] Barnes ME, Hanten RP, Cordes RJ, Sayler WA, Carreiro J. Reproductive performance of inland fall Chinook Salmon. N Am J Aquaculture 2000; 62: 203-11. [http://dx.doi.org/10.1577/1548-8454(2000)062<0203:RPOIFC $>2.3 . C O ; 2]$

[2] Johnson HE, Brice RF. Effects of transportation of green eggs, and of water temperature during incubation, on the mortality of Chinook Salmon. Prog Fish-Cult 1953; 15: 104-8. [http://dx.doi.org/10.1577/1548-8640(1953)15[104:EOTOGE]2.0.CO;2]

[3] Banks JL, Fowler LG. Transportation, storage and handling studies of fall Chinook Salmon gametes and newly fertilized eggs Abernathy Salmon Cultural Development Center, Technology Transfer Series 82-4. US. Fish Wildlife Service 1982.

[4] Marrone GM, Stout DA. Whitlocks Bay Spawning station annual report 97-119. South Dakota Department Game, Fish and Parks. Ann Rep 1997; 1997: 97-119.

[5] Quinn TP. The behavior and ecology of Pacific Salmon and Trout. Seattle, Washington: University of Washington Press 2005.

[6] Iwamoto RN, Sower S. Salmonid reproduction an international symposium. Seattle, Washington: University of Washington Press 1983; pp. 44-8.

[7] Poston HA, Ketola HG. Chemical composition of maturing and spawning Atlantic Salmon from different locations. Prog Fish-Cult 1989; 51: 133-9.

[http://dx.doi.org/10.1577/1548-8640(1989)051<0133:CCOMAS>2.3.CO;2]

[8] Gjerde B, Gunnes K, Gjedrem T. Effect of inbreeding on survival and growth in rainbow trout. Aquaculture 1983; 34 : 327-32. [http://dx.doi.org/10.1016/0044-8486(83)90212-0]

[9] Araki H, Berejikian BA, Ford MJ, Blouin MS. Fitness of hatchery-reared Salmonids in the wild. Evol Appl 2008; 1(2): $342-55$. [http://dx.doi.org/10.1111/j.1752-4571.2008.00026.x] [PMID: 25567636]

[10] Machlin LJ. Handbook of vitamins. New York: Marcel Dekker, Inc. 1991.

[11] Hill TD. Life history and bioenergetics of Chinook Salmon in Lake Oahe, South Dakota. Brookings, South PhD Dissertation. Dakota: South Dakota State University 1997.

[12] Gnaedinger RH. Thiaminase activity in fish: An improved assay method. Fish Ind Res 1964; 2: 55-9.

[13] Ji YQ, Adelman IR. Thiaminase activity in alewives and smelt in Lakes Huron, Michigan, and Superior. In: McDonald G, Fitzsimons JD, Honeyfield DC, Eds. In: Early life stage mortality syndrome in fishes of the Great Lakes and Baltic Sea Am Fish Soc Symp 1998; 21: pp. 154-9.

[14] Fitzsimons JD, Brown SB. Reduced egg thiamine levels in inland and Great Lakes lake Trout and their relationship with diet. In: Fitzsimons JD, Honeyfield DC, Eds. In: Early life stage mortality syndrome in fishes of the Great Lakes and Baltic Sea Am Fish Soc Symp. 1998; 21: pp. 160-71.

[15] Bylund G, Lerche O. Thiamine therapy of M74 affected fry of Atlantic Salmon Salmo salar. Bull Eur Assoc Fish Pathol 1995; 15 : 93-7.

[16] Fitzsimons JD. The effect of B-vitamins on a swim-up syndrome in Lake Ontario lake Trout. Great Lakes Res 1995; $21: 286-9$. [http://dx.doi.org/10.1016/S0380-1330(95)71102-9]

[17] Fynn-Aikins K, Bowser PR, Honeyfield DC, Fitzsimons JD, Ketola GH. Effect of dietary amprolium on tissue thiamine and Cayuga syndrome in Atlantic Salmon. Trans Am Fish Soc 1998; 127: 747-57. [http://dx.doi.org/10.1577/1548-8659(1998)127<0747:EODAOT>2.0.CO;2]

[18] Amcoff P, Norrgren L, Borjeson H, Linderberg J. Lowered concentrations of thiamine (vitamin B1) in M74-affected feral Baltic Salmon (Salmon salar). Sweden: Rapport-Naturvaardsverket 1996. 
[19] Brown SB, Fitzsimons JD, Honeyfeild DC, Tillitt DE. Implications of thiamine deficiency in Great Lakes Salmonines. J Aquat Anim Health 2005; 17: 113-24

[http://dx.doi.org/10.1577/H04-015.1]

[20] Fisher JP, Brown SB, Wooster GW, Bowser PR. Maternal blood, egg and larval thiamin levels correlate with larval survival in landlocked Atlantic Salmon. J Nutr 1998; 128(12): 2456-66. [PMID: 9868194]

[21] Riley SC, Rinchard J, Honeyfield DC, Evans AN, Begnoche L. Increasing thiamine concentrations in lake trout eggs from Lakes Huron and Michigan coincide with low alewife abundance. N Am J Fish Manage 2011; 31: 1052-64. [http://dx.doi.org/10.1080/02755947.2011.641066]

[22] Barnes ME, Zehfus MH, Schumacher JA, et al. Maternal liver and egg thiamine concentrations in Chinook Salmon from Lake Oahe, South Dakota. Prairie Nat 2003; 35: 113-7.

[23] Lott J, Marrone G, Stout D. Influence of size-and-date at stocking, imprinting attempts and growth on initial survival, homing ability, maturation patterns and angler harvest of Chinook Salmon in Lake Oahe, South Dakota. Progress Report 97-20. Pierre, South Dakota: South Dakota Department Game, Fish Parks 1997.

[24] Barnes ME, Wipf MM, Domenici NR, Kummer WM, Hanten RP. Decreased hatchery rearing density improves post-stocking harvest and return to spawning of landlocked fall Chinook Salmon. N Am J Aquaculture 2013; 75: 244-50. [http://dx.doi.org/10.1080/15222055.2013.768573]

[25] Piper RG, McElwain IB, Orme LE, McCraren JP, Fowler LG, Leonard JR. Fish Hatchery Management. Washington, DC: US. Fish and Wildlife Service 1982.

[26] Brown SB, Honeyfield DC, Vandenbyllaardt L, McDonald G, Fitzsimons JD, Honeyfield DC. Thiamine analysis in fish tissues. In: Early life stage mortality syndrome in fishes of the Great Lakes and Baltic Sea. Am Fish Soc Symp 1998; 21: pp. 73-81.

[27] Fisher JP, Brown SB, Connelly S, Chiottie T, Krueger CC. Interspecies comparisons of blood thiamine in salmonids from the Finger Lakes, and effect of maternal size on blood and egg thiamine in Atlantic Salmon with and without Cayuga syndrome. In: McDonald G, Fitzsimons JD, Honeyfield DC, Eds. Early life stage mortality syndrome in fishes of the Great Lakes and Baltic Sea. Am Fish Soc Symp 1998; 21: pp. 112-23.

[28] Ketola GH, Bowser PR, Wooster GA, Wedge LR, Hurst SS. Effects of thiamine on reproduction of Atlantic Salmon and a new hypothesis for their extirpation in Lake Ontario. Trans Am Fish Soc 1999; 129: 607-12. [http://dx.doi.org/10.1577/1548-8659(2000)129<0607:EOTORO >2.0.CO;2]

[29] Wooster GA, Bowser PR, Brown SB, Fisher JP. Remediation of Cayuga Syndrome in landlocked Atlantic Salmon Salmo salar using egg and sac-fry bath treatments of thiamine-hydrochloride. J World Aquacult Soc 2000; 31: 149-57. [http://dx.doi.org/10.1111/j.1749-7345.2000.tb00348.x]

[30] Wolmagood M, Hnath JG, Brown SB, et al. Temporal and spatial variation of early mortality syndrome in Salmonids from Lakes Michigan and Huron. J Aquat Anim Health 2005; 17: 65-76. [http://dx.doi.org/10.1577/H03-077.1]

[31] Fitzsimons JD, Williston B, Williston G, et al. Egg thiamine status of Lake Ontario Salmonines 1995-2004 with emphasis on lake Trout. J Great Lakes Res 2007; 33: 93-103. [http://dx.doi.org/10.3394/0380-1330(2007)33[93:ETSOLO]2.0.CO;2]

[32] Rolland RM, Gilbertson M, Peterson RE. Chemically induced alterations in functional development and reproduction of fishes: Proceedings from a session at the 1995 Wingspread Conference. Pensacola: Society of Environmental Toxicology and Chemistry (SETAC) 1997; 146-60.

[33] Koski P, Soivio A, Hartikainen K, Hirvi T, Myllyla T. M74 syndrome and thiamine in Salmon broodfish and offspring. Boreal Environ Res 2001; 6: 79-92.

[34] Ketola HG, Johnson JH, Rinchard J, et al. Effect of thiamine status on probability of Lake Ontario Chinook Salmon spawning in the upper and lower sections of the Salmon River, New York. N Am J Fish Manage 2009; 29: 895-902. [http://dx.doi.org/10.1577/M08-021.1]

[35] Tillit DE, Zajicek JE, Brown SB, et al. Thiamine and thiaminase status in forage fish of Salmonines from Lake Michigan. J Aquat Anim Health 2005; 17: 13-25.

[http://dx.doi.org/10.1577/H03-081.1]

[36] Hirn J, Pekkanen TJ. Quantitative analysis of thiaminase activity in certain fish species. Nord Vet Med 1975; 27(12): 646-8. [PMID: 1196856]

[37] Brown SB, Arts MT, Brown LR, et al. Can diet-dependent factors help explain fish-to-fish variation in thiamine-dependent early mortality syndrome? J Aquat Anim Health 2005; 17: 36-47.

[http://dx.doi.org/10.1577/H03-072.1]

[38] Barnes ME, Hanten RP, Sayler WA, Cordes RJ. Viability of inland fall Chinook Salmon spawn containing overripe eggs and the reliability of egg viability estimates. N Amer J Aquac 2000; 62: 237-9. [http://dx.doi.org/10.1577/1548-8454(2000)062<0237:VOIFCS $>2.3 . C O ; 2]$

[39] Ahlgren GL, Nieuwerburgh V, Wänstrand I, Pedersén M, Boberg M, Snoeijs P. Imbalance of fatty acids in the base of the Baltic Sea food web: A mesocosm study. Can J Fish Aquat Sci 2005; 62: 2240-53. 
[http://dx.doi.org/10.1139/f05-140]

[40] Vuori KA, Nikinmaa M. M74 syndrome in Baltic Salmon and the possible role of oxidative stresses in its development: Present knowledge and perspectives for future studies. Ambio 2007; 36(2-3): 168-72.

[http://dx.doi.org/10.1579/0044-7447(2007)36[168:MSIBSA]2.0.CO;2] [PMID: 17520930]

[41] Czesny S, Dettmers JM, Rinchard J, Dabrowski K. Linking egg thiamine and fatty acid concentrations of Lake Michigan lake Trout with early life stage mortality. J Aquat Anim Health 2009; 21(4): 262-71. [http://dx.doi.org/10.1577/H07-056.1] [PMID: 20218500]

[42] Keinänen M, Uddström A, Mikkonen J, et al. The thiamine deficiency syndrome M74, a reproductive disorder of Atlantic Salmon (Salmo salar) feeding in the Baltic Sea, is related to the fat and thiamine content of prey fish. ICES J Mar Sci 2012; 69: 516-28. [http://dx.doi.org/10.1093/icesjms/fss041]

[43] Johnston TA, Leggett WC. Maternal and environmental gradients in the egg size of an iteroparous fish. Ecol Soc Amer 2002; 83: 1777-91.

[44] Brown SB, Honeyfield DC, Hnath JG, et al. Thiamine status in adult Salmonines in the Great Lakes. J Aquat Anim Health 2005; 17 : 59-64. [http://dx.doi.org/10.1577/H04-059.1]

[45] Fitzsimons JD, Williston B, Amcoff P, et al. The effect of thiamine injection on upstream migration, survival and thiamine status of putative thiamine-thiamine deficient coho Salmon. J Aquat Anim Health 2005; 17: 48-58.

[http://dx.doi.org/10.1577/H04-003.1]

[46] Brown SB, Fitzsimons JD, Palace VP, Vandenbyllaardt L. Thiamine and early mortality syndrome in lake trout. In: McDonald G, Fitzsimons JD, Honeyfield DC, Eds. Early life stage mortality syndrome in fishes of the Great Lakes and Baltic Sea. Am Fish Soc Symp 1998; 21: pp. 18-24.

[47] Honeyfield DC, Hinterkopf JP, Fitzsimons JD, Tillitt DE, Zajicek JL, Brown SB. Development of thiamine deficiencies and early mortality syndrome in lake Trout by feeding experimental and feral fish diets containing thiaminase. J Aquat Anim Health 2005; 17: 4-12. [http://dx.doi.org/10.1577/H03-078.1]

[48] Gall GA. Influence of size of eggs and age of female on hatchability and growth in rainbow trout. Calif Fish Game 1974; 60: $26-36$.

[49] Fowler LG. Growth and mortality of fingerling Chinook Salmon as affected by egg size. Prog Fish-Cult 1972; 34: 66-9. [http://dx.doi.org/10.1577/1548-8640(1972)34[66:GAMOFC]2.0.CO;2]

[50] Estay F, Diaz NF, Neira R, Garcia X. Reproductive performance of female coho Salmon in Chile. Prog Fish-Cult 1997; 59: 36-40. [http://dx.doi.org/10.1577/1548-8640(1997)059<0036:RPOCFC $>2.3 . C O ; 2]$

[51] Hamoutene D, Lush L, Drover D, Walsh A. Investigation of the temporal effects of spawning season and maternal and paternal differences of egg quality in Atlantic cod Gadus morhua. Broodstock. Aquacult Res 2009; 40: 1668-79. [http://dx.doi.org/10.1111/j.1365-2109.2009.02271.x]

[52] Beacham TD, Murray CB. Variation in developmental biology of sockeye Salmon (Oncorhynchus nerka) and Chinook Salmon (O. tshawytscha) in British Columbia. Can J Zool 1989; 67: 2081-9. [http://dx.doi.org/10.1139/z89-297]

[53] Geist DR, Abernethy CS, Hand KD, Cullinan VI, Chandler JA, Groves PA. Survival, development, and growth of fall Chinook Salmon embryos, alevins, and fry exposed to variable thermal and dissolved oxygen regimes. Trans Am Fish Soc 2006; 135: 1462-77. [http://dx.doi.org/10.1577/T05-294.1]

[54] Hanten RP. Whitlocks Bay Salmon Spawning Station report 11-02. Pierre, South Dakota: South Dakota Department of Game, Fish and Parks 2011.

[55] Stone CC, Nealson P. An estimate of abundance and distribution of rainbow smelt in Lake Oahe reservoir using hydroacoustic techniques, 1988-1989. Progress Report 90-8. Pierre, South Dakota: South Dakota Department of Game, Fish and Parks 1990.

\section{(C) 2017 Doyle et al.}

This is an open access article distributed under the terms of the Creative Commons Attribution 4.0 International Public License (CC-BY 4.0), a copy of which is available at: (https://creativecommons.org/licenses/by/4.0/legalcode). This license permits unrestricted use, distribution, and reproduction in any medium, provided the original author and source are credited. 